\title{
A Review Disaster Mitigation of Jakarta Land Subsidence Areas
}

\author{
Ratih Fitria Putri $^{1 *}$, Mya Dwi Rostika ${ }^{2}$, Aji Wijaya Abadi ${ }^{1}$, and Mega Rakhmatika ${ }^{1}$ \\ ${ }^{1}$ Department of Environmental Geography, Faculty of Geography, Universitas Gadjah Mada, Indonesia \\ ${ }^{2}$ Department of International Relations, Faculty of International Relations, Daito Bunka University, Japan \\ *Corresponding author: ratihfitria.putri@ugm.ac.id
}

\begin{abstract}
The Jakarta Capital Special Region of Jakarta is an area in the Java Island that has the highest level of vulnerability to land subsidence disasters. Land subsidence is caused by several factors such as excessive use of groundwater and natural compression of soil conditions. This study used a review analysis method based on a literature study on mitigation of land subsidence disasters in Jakarta city. The mitigation planning of land subsidence disasters in Jakarta will refer to government regulations on disaster management and Jakarta City spatial planning. Disaster mitigation is necessary to anticipate or reduce disaster risk. Disaster mitigation is a series of efforts to reduce disaster risk through physical development combined with awareness and capacity building in dealing with disaster threats. Education cannot be separated from the active role of the community and local government. High-densely populated areas will lead to more use of groundwater in Jakarta city. The excessive use of groundwater has resulted in more intensive land subsidence in Jakarta's urban area. The safe zone mapping of subsidence disasters is prominent to reduce and control land subsidence disasters. The government's efforts to lessen the impacts of land subsidence are by educating the population in disaster areas.
\end{abstract}

\section{Introduction}

Indonesia is an archipelago country that has a very high risk of natural disasters [1]. The disaster risks faced by Indonesia include natural disasters caused by geological factors (landslides, earthquakes, volcanic eruptions, and tsunamis), hydrometeorological factors (floods, landslides, droughts, hurricanes), disasters due to biological factors (human disease outbreaks, plant/livestock diseases) and technological failures (industrial accidents, transportation accidents, nuclear radiation, chemical pollution). Land subsidence is among natural disasters that take place annually and become a general concern to the big city in local government.

The Capital Special Region of Jakarta has the highest vulnerability to land subsidence disasters (Figure 1). Land subsidence is induced by various factors such as excessive groundwater withdrawal and natural compression of soil conditions. Land subsidence is highly potential in causing other problems such as changes in topographic gradients, damage to the soil surface, and reduction of groundwater-contained aquifer capacity. Land subsidence has an impact on the development of regional development conditions both locally and regionally. The phenomenon of land subsidence can increase the potential of flooding in an area [2]. In Jakarta, land subsidence is one of the significant causes of the January 2013 flood disaster [3].

The research area has 13 natural and artificial rivers for locals' drinking water and other domestic needs. Jakarta City has a tropical climate with annual rainfall reaches $1,755 \mathrm{~mm}$ or approximately $146 \mathrm{~mm}$ per month. Currently, Jakarta's development level has advanced rapidly following urbanization. According to the 2020 census data, the population density of Jakarta City is estimated at 15,964 people/ $\mathrm{Km}^{2}$ [4]. The Jakarta Capital Special Region map is showed in Figure 2.

As a result of losses caused by disasters generated by land subsidence, innovations in disaster mitigation planning to overcome and reduce disaster risk need to be carried out effectively and systematically to reduce inaccuracies in the disaster mitigation process and prevent overlaps in the implementation of disaster mitigation [5]. This study aims to analyze land subsidence mitigation in Indonesia as review process in local government disaster management.

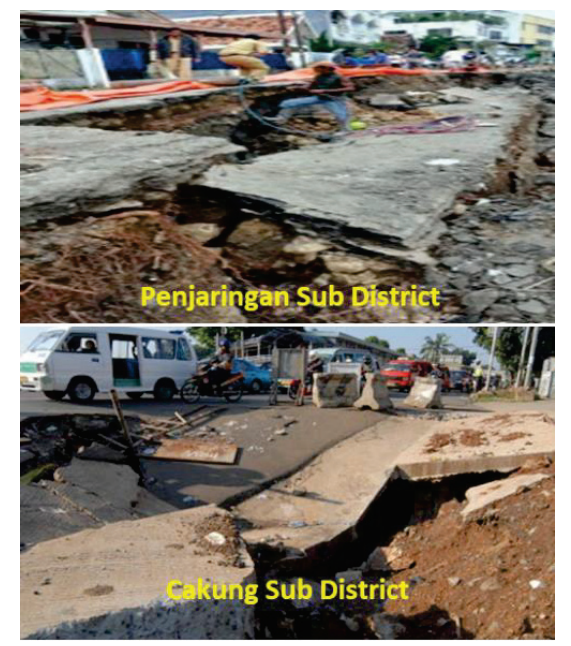


Fig. 1. Land Subsidence Areas in the Jakarta City.

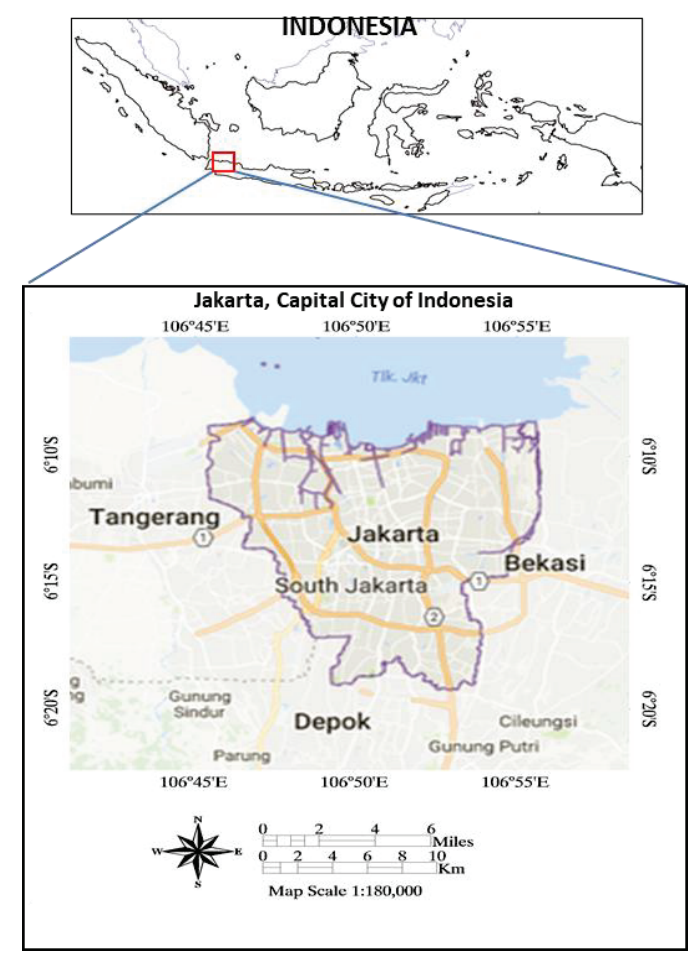

Fig. 2. Jakarta Special Capital Region Map.

\section{Methods}

This study applied a review analysis method according to a literature study on land subsidence disasters mitigation in Jakarta City. Data of land subsidence has been examined based on research using differential interferometry synthetic aperture radar [6]. The predetermined area for land subsidence analysis is in the northern part of the city of Jakarta. Disaster mitigation planning of land subsidence in Jakarta will refer to government regulations on disaster management and Jakarta City spatial planning [7].

\section{Results and Discussions}

\subsection{Population Analysis}

The burgeoning population density from year to year and the increasing number of settlements in Jakarta city are some causes of the land-use intensification in land subsidence-prone areas [5]. Land use in Jakarta City is a noticeable result of a long process of constant interaction, balance, and dynamics between the population activities on land and the environment limiting factors [6]. Land-use change can affect local ecological systems by water pollution, air pollution, climate change, and declining biodiversity. Population growth and progressing economic activity over time increase the necessity of resources, including space. Space remains fixed in a broad sense but, it will always change following changes in space utilization regarding physical, economic, and social composition. Changes in spatial use that do not consider the geo-biophysical balance will produce waste and result in natural disasters. Jakarta is one of the largest cities in Indonesia and population of $10,560,000$ people in 2020. As the capital of Indonesia, Jakarta plays a vital role in the economy and the central government. The development of urban areas is a response to increasing population growth in Jakarta City. Therefore, it has become one of the triggers for various environmental problems in this decade.

This research will highlight three areas that have the highest level of subsidence. The areas to be analyzed are Mutiara Beach, Cengkareng, and Cakung. According to statistics of the population density of the Jakarta Province, the predetermined areas are densely populated. Mutiara Beach, Cengkareng, and Cakung have a population density of 8,635 people/ $\mathrm{Km}^{2}, 19,363$ people $/ \mathrm{Km}^{2}$, and 11,919 people/ $/ \mathrm{Km}^{2}$ respectively. Jakarta's population tends to increase every year. The high population density occurred in Central Jakarta and West Jakarta at more than $18,000 / \mathrm{Km}^{2}$. From the perspective of the population density, the denser the population, the higher the rate of land subsidence. Population density is directly proportional to the population. Therefore, the increasing number of residents from year to year considerably affects the increase in population density. One example of human activities that cause land subsidence is excessive groundwater extraction. The larger the population size in a certain area, the higher the demand for clean water to sustain their activities. Anointing is one way to fulfill the need for clean water in the community. Based on the 2020 statistics, the Cakung District consists of eight villages in which the Grinding Village has the largest population density value of 23,277 people $/ \mathrm{Km}^{2}$. West Cengkareng has the largest population density in Cengkareng District with a value of 20,217 people $/ \mathrm{Km}^{2}$. A population density of 29,868 people $/ \mathrm{Km}^{2}$ makes Penjaringan Village the most densely populated village in the Penjaringan District. Based on the value of the largest population density, it can be concluded that the highest potential for land subsidence is in the village in each of these sub-districts.

The problem of population and environmental damage are two things that pertain to each other. The occurrence of environmental damage which results in the imbalance of natural resources can affect human life at a macro level. Consequently, the imbalance between the population growth rate and the quality of natural resources can destroy all human life. Therefore, wise efforts are needed in the future to maintain environmental sustainability. This concept attempts to balance population with all its needs while sustaining environmental quality. Accordingly, the stability between population growth rate and environmental sustainability can be obtained. 


\subsection{Land Subsidence}

Land subsidence is one of the impacts of the increasing development in Jakarta. Urbanization has resulted in a very high demand for residential land, making Jakarta city possessing various kinds of environmental problems. Jakarta is the largest city in the country that serves as the center of Indonesian politics and economic activity. The existence of these urban functions has resulted in the increasing potential for land subsidence in Jakarta. Three locations have experienced considerable land subsidence, namely Mutiara Beach, Cengkareng, and Cakung [5]. Mutiara Beach has land subsidence ranging from $8.5-10.9 \mathrm{~cm} /$ year. Land subsidence in Cengkareng ranges from 10 to 17.5 $\mathrm{cm} /$ year. Cakung experienced land subsidence of $7.5-$ $9.5 \mathrm{~cm} /$ year.

Penjaringan District is in the northern part of Jakarta that has a coastal reclamation area. The reclamation process of the Jakarta coastal area is a government plan aimed at controlling flooding in the city of Jakarta and developing a rapidly growing business area. The reclamation was conducted by building a $60 \mathrm{~km}$ sea embankment in Jakarta Bay.

The land subsidence in Cengkareng is more impactful than in other areas in the city of Jakarta. Cengkareng is a district in West Jakarta with an area of $27.9 \mathrm{~km} 2$. The maximum land subsidence in the area is $17.5 \mathrm{~cm} /$ year. This subsidence event is triggered by human activities such as building construction and groundwater extraction. Cengkareng's land use consists of 1.10 residential areas and 97.25 ha industrial areas. The estimated rate of land subsidence in Cengkareng is in the range of 10.0-17.5 cm/year.

Cakung is one of the suburbs of Jakarta. Land subsidence in the Cakung area ranges from 7.5 to 9.5 $\mathrm{cm} /$ year. The majority of land in Cakung is used for residential areas and industrial zones. The residential areas make up $45.27 \%$ of the Cakung area while the industrial zones cover $24.33 \%$ of the rest. The district is addressed for industrial activities with the most frequent industrial activities operate in the Pulogadung area.

Land subsidence can trigger a disaster. Rob flood induced by land subsidence occurs in the Penjaringan District. The disaster risk is even more as Penjaringan District is highly developed and more vulnerable highvalued assets are exposed. The northern part of Penjaringan District has land use resulted from coastal reclamation. The north side of the district is an elite housing zone and exclusive apartments. This condition stimulated the increasingly extensive use of groundwater in the northern part of Penjaringan.

Cengkareng District's land has majorly been developed. Dense village settlements are the dominant land use. The load due to the existing land use can make the soil more compressed. Soil compression will cause land subsidence in Cengkareng District. Furthermore, over groundwater withdrawal from the settlements can accelerate land subsidence.

Cakung District is located on the easternmost part of East Jakarta, neighboring West Java Province. Its strategic location allows Cakung District has adequate transportation facilities. Warehouses and industries are the general land use found in the Cakung District. The presence of industries, warehouses, and houses in the Cakung District produces a large surface load. The high demand for water and the overuse of groundwater leads to groundwater depletion. When the volume of groundwater declined while the pressure from the surface increased, the phenomenon of land subsidence can occur more intensively.

\subsection{Disaster Mitigation}

Population adaptation to land subsidence has been a better strategy for managing the hazard. Some adaptations have been implemented by the community, such as creating traditional embankments and raising houses hence they will not be inundated by the flood [8]. Flooding is one of the disasters that resulted from land subsidence in Jakarta City. Disaster awareness of the land subsidence and its consequences has improved. The government attempts to reduce the risks of land subsidence by educating the population in disasterprone areas so the capacity of the community increase. The education process can succeed if the community and the local government play active roles and support each other. Besides, spatial planning in Jakarta city must be appropriate so that there is no excessive groundwater extraction. The higher population density means higher settlement density as well. A densely populated area will drive more demand for groundwater in Jakarta City. Over groundwater extraction has stimulated more intense land subsidence in Jakarta's urban area. Therefore, safe zone mapping of subsidence is significant to reduce and control the disaster. The safe zone is determined by monitoring the land subsidence every year in Jakarta. The annual land subsidence measurements have to be carried out thoroughly to know the existing condition accurately.

\section{Conclusions}

Disaster mitigation is needed to anticipate or lessen the risk of natural disasters. Disaster mitigation is defined as a series of efforts to lower disaster risk that can be implemented through physical development, awareness enhancement, and capacity building in dealing with disaster threats. Disaster can occur at any time with or without warning. Therefore, we must be ready whenever and wherever we are. The most important thing is to keep following the directions of the authorized officers. Disaster mitigation can be applied in any form, such as introducing and monitoring disasters, developing a disaster awareness culture, and implementing cuttingedge technology to anticipate disaster risks. Those activities can help to improve spatial planning and development, reduce the impact of disasters, and upgrade public knowledge. Finally, the community has stronger resilience to cope with disasters that potentially occur in their surrounding environment. 


\section{References}

1. R. F. Putri, A. W. Abadi, and U Kafafa. The correlation analysis between urbanization phenomena and landuse change in Jakarta Special Province. E3S Web of Conferences 200, 05003 (2020)

2. H. Z. Abidin, H. Andreas, I. Gumilar, M. Gamal, Y. Fukuda, Y. E. Pohan, and T. Deguchi, T. Land subsidence of Jakarta (Indonesia) and its relation with urban development, Nat Hazards, 59:17531771 (2011)

3. M. D. Anisuzzaman, Dicky, M. Arifuzzaman, and N. Shadrina. The Role of Clay Minerals n LandSubsidence: A Case Study in Jakarta, Indonesia Case Study in Jakarta, Indonesia". The $3^{\text {rd }}$ International Conference on Ecological, Environmental and Biological Sciences Proceeding. 188-191 (2013)

4. BPS DKI Jakarta, DKI Jakarta dalam Angka Tahun 2020. Jakarta: Badan Pusat Statistik, 2020.

5. R. F. Putri, L. Bayuaji, J. T. S. Sumantyo, and H. Kuze, "Terrasar-X DInSAR for land deformation detection in Jakarta Urban area, Indonesia," $J$. Urban Environ. Eng., vol. 7, no. 2, pp. 195-205. (2013)

6. R. F. Putri, S. Wibirama, S. R. Giyarsih, A. Pradana, and Y. Kusmiati, "Landuse change monitoring and population density analysis of Penjaringan, Cengkareng, and Cakung Urban Area in Jakarta Province," E3S Web Conf., vol. 76. (2019)

7. Dinas Tata Ruang Provinsi DKI Jakarta. Rencana Tata Ruang Wilaya 2011-2030. Available in: http://webgis.tatakota-jakartaku.net/. Access on 3 June 2014.

8. G. Erkens and E. Stouthamer. The $6 \mathrm{M}$ approach to land subsidence. Proc. IAHS, 382, 733-740. (2020) 